\title{
Development of a Simplified Slow Sand Filter for Water Purification
}

\author{
1*YUSUF, KO; ${ }^{2}$ ADIO-YUSUF, SI; ${ }^{3}$ OBALOWU, RO \\ ${ }^{I}$ Department of Agricultural and Biosystems Engineering, University of Ilorin, ${ }^{2}$ Department of Water Resources and Environmental \\ Engineering, Ilorin, Kwara State, Nigeria \\ ${ }^{3}$ Department of Agricultural and Bio-Environmental Engineering Technology. Institute of Technology, Kwara State Polytechnic, Ilorin, \\ Nigeria \\ *Corresponding Author Email: kamaru.yusuf@yahoo.com; yusuf.ok@unilorin.edu.ng; other Authors Emails: abrashaola@gmail.com; \\ adio@unilorin.edu.ng
}

\begin{abstract}
This study reports the development of a simplified slow sand filter with granular carbon for water purification which could be used for teaching. It was fabricated using transparent perspex glass for the filter chamber, PVC pipe, fine sand, coarse sand and granular carbon for removal of physicochemical and pathogens in the contaminated water. The filter has a50 litres storage tank from which raw water flows into the filter chamber through the pipe. The filter chamber ( 30 by $30 \mathrm{~cm}$ and $100 \mathrm{~cm}$ high) has $10 \mathrm{~cm}$ layer of granular carbon, three sand layers as the filter bed $(30 \mathrm{~cm}$ depth with grain size $0.20 \mathrm{~mm}, 20 \mathrm{~cm}$ with grain size $0.35 \mathrm{~mm}$ and $10 \mathrm{~cm}$ with gravel $6.00 \mathrm{~mm}$ ). Water samples were collected from Asa River. The water sample was poured into the water filter; water samples were collected and analyzed. The filter has a capacity for producing $15.25 \mathrm{litres} / \mathrm{h}$ of clean water. The values of turbidity, $\mathrm{pH}$, Electrical conductivity, Calcium, Magnesium, Sodium, Potassium, Iron II, Colonies growing on nutrient agent at $37^{\circ} \mathrm{C}$ in 24 hours and E-Coli for the filtered water were $0.91 \mathrm{mg} / 1,6.7,26.8 \mu \mathrm{S} / \mathrm{cm}, 12.6 \mathrm{mg} / 1,16.0 \mathrm{mg} / 1,0.82 \mathrm{mg} / 1,0.31 \mathrm{mg} / 1,0.12 \mathrm{mg} / 1,12$ and 8 , respectively while the corresponding values for non-filtered water were $6.7 \mathrm{mg} / 1,7.2,83.7 \mu \mathrm{S} / \mathrm{cm}, 28.0 \mathrm{mg} / 1,20.0 \mathrm{mg} / \mathrm{l}, 1.63 \mathrm{mg} / \mathrm{l}$, $0.72 \mathrm{mg} / \mathrm{l}, 0.65 \mathrm{mg} / \mathrm{l}, 40$ and 13 . The filter reduced E-Coli present in the water by $69 \%$. The slow sand water filter could be used in the school laboratory as a water treatment prototype device for teaching students.
\end{abstract}

\section{DOI:https://dx.doi.org/10.4314/jasem.v23i3.3}

Copyright: Copyright (C) 2019 Yusuf et al. This is an open access article distributed under the Creative Commons Attribution License (CCL), which permits unrestricted use, distribution, and reproduction in any medium, provided the original work is properly cited.

Dates: Received: 30 January 2019; Revised: 29 February 2019; Accepted 212 March 2019

Keywords: slow sand filter, water quality, water treatment, granular carbon

Potable water is indispensable for survival of human race and the demand for potable water is increasing because of the population growth. Potable water is the water that is free from pathogens, colourless, odourless and the chemicals composition are within the acceptable limits which is safe for consumption without causing any disease to man. Raw water from streams, rivers, ponds, lake and even rain water from roof are usually contaminated with pathogens that can cause some deadly diseases to man. Contaminated water can cause water-borne diseases such as typhoid, cholera, dysentery and some other diseases (Hammer and Hammer, 2012). There is need for purification of water from ponds and streams to prevent certain diseases in the rural areas where tap water (public treated water) is rarely available. There is also need to expose undergraduate students to some basic methods of water purification in the treatment plant using a simple or prototype water filter in the school laboratory. Modern water filtration devices are available but some of them needed electricity to power its operation which is lacking in rural areas and even in some laboratories in the developing countries. A water filter such as slow sand water filter does not requires electric power for its operation, relatively cheapand could be used in school laboratories for teaching students on how filtration is done in the water treatment plant and could also be used in rural areas for water purification. Slow sand water filter is effective for water purification and it uses the filtration method to remove dissolved particles and microorganisms in the water (Basak, 2003 and Chatterjee, 2007). A slow sand water filter could effectively remove some toxic chemicals and hazardous materials from the water (El-Harbawi et al., 2010). Basak (2003) also indicated that slow sand filter could improve the chemical, physical and biological properties of water when water is allowed to flow through it. WHO (1996) stated that slow sand filter could remove between 98 and $99 \%$ of the diseases causing pathogens and this could significantly reduce the diseases caused by pathogens.

Filtration by silk cloth to remove debris and other particles in rural areas in olden day was not effective for water purification because it does not remove colour, odour, taste, most chemicals and does not totally remove pathogens that could cause deadly

*Corresponding Author Email: kamaru.yusuf@yahoo.com; yusuf.ok@unilorin.edu.ng; other Authors Emails: abrashaola@gmail.com; adio@unilorin.edu.ng 
disease to man. Slow sand filter differ because it uses biofilm layer that grows naturally on the surface of the wet sand called schmutzdecke to trap and kill the bacteria in the contaminated water. Biofilm is the biological active film that coats the sand media of a slow sand filter and it helps in the removal of contaminants (Hendrick, 1991). The sand acts as a substrate upon which the biological film developed (Wirojanagud et al., 1998). The development of biofilm layer is possible due to the absence of predisinfectant on the sand filter bed (Lahlou, 2000). The biofilm layer (schmutzdecke) normally develop $2-3$ weeks after the construction of the slow sand filter and the filter bed must be wet (Buzunis, 1995). The water reservoir that supplies water to the filter chamber could be 1 to $1.5 \mathrm{~m}$ above the sand bed. The space above the sand filter bed to the top of the filter chamber is called supernatant or top-water and it provides the pressure that carry the water through the filter bed. When water flows downward through the filter bed, it enters the intensely active biofilm layer, where various microorganisms entrapped, digested and break down the organic matter contained within it (Shoemaker, 2014). Visscher et al. (1987) recommended three layers for slow sand filter, the grain size for the layer and the depths (thickness) for grain. For the coarse sand of diameter $1.0-1.4 \mathrm{~mm}(10 \mathrm{~cm}$ thickness $)$, gravel of diameter $4.0-5.6 \mathrm{~mm}$ (10 cm thickness) and gravel of diameter $16.0-23.0 \mathrm{~mm}$ ( $15 \mathrm{~cm}$ thickness). Visscher et al. (1987) recommended a minimum depth of $60 \mathrm{~cm}$ of filter bed for purification of water by slow sand filter. The slow sand filter chamber could be constructed from galvanized sheet or plastic material (PVC). The objective of this study was to develop a simple laboratory slow sand filter with granular carbon and to determine the effect of the filter on some physical, chemical and biological properties of a river water.

\section{MATERIALS AND METHODS}

Description of the water filter: The laboratory and household water filter was designed and fabricated (developed) using locally available materials that are relatively cheap and readily available in Ilorin, Kwara State, Nigeria. The water purifier (water filter) was fabricated using a transparent perspex glass of thickness $4 \mathrm{~mm}$ for the filter chamber. The filter chamber was 30 by $30 \mathrm{~cm}$ and $100 \mathrm{~cm}$ high. The filter chamber was transparent perspex glass to enable students see the movement of water through the filter bed before it is collected at the outlet whenever the filter is used for demonstration. The sand used as filter medium was freely running sand sieved through 0.20 $\mathrm{mm}, 0.35 \mathrm{~mm}$ and gravel sieved through $6.00 \mathrm{~mm}$. The sand was put in water for 48 hours, thoroughly washed to remove organic matter, colloids and some soluble minerals in water, and sun-dry for 3 days. Washing of sand filter material is necessary to have a clean filter bed that free from debris, organic matter, clay particles and some soluble chemicals.

World Health Organization (WHO) recommended that a non-reactive material such as plastic (PVC) and fiberglass should be used for the filter chamber. The filter chamber was fabricated using transparent perspex glass so that flow of water through the filter bed could be seen and easily monitored by the students when the filter is being used for demonstration. The filter chamber ( 30 by $30 \mathrm{~cm}$ and $100 \mathrm{~cm}$ high) has 10 $\mathrm{cm}$ depth containing granular carbon (sieved through $2 \mathrm{~mm}$ ) put in a muslin bag and three sand layers as filter bed of $60 \mathrm{~cm}$ depth $(30 \mathrm{~cm}$ grain size $0.20 \mathrm{~mm}$, $20 \mathrm{~cm}$ grain size $0.35 \mathrm{~mm}$ and $10 \mathrm{~cm}$ gravel 6.00 $\mathrm{mm}$ ). The water filter has a 50 litres storage tank for the raw water to be filtered and it is connected to the filter chamber by $25.4 \mathrm{~mm}$ ( $1 \mathrm{inch}$ ) diameter PVC pipe. The water outlet from the storage tank through the pipe has a control tap for regulating the flow of water from the tank into the filter chamber.

The supernatant is the water reservoir space above the sand filter layer. The depth between the biofilm layer and top of the filter chamber was $30 \mathrm{~cm}$. The depth of water in the supernatant provides the required pressure (pressure head) to push the water through the filter media. The supernatant must be filled with water to keep the biofilm layer moist for proper functioning of the slow sand filter. The exploded view and picture of the slow sand filter were shown in Figures 1 and 2.

Fabrication of the slow sand filter: A 30 by $100 \mathrm{~cm}$ (4 pieces) was marked out on the perspex glass and cut using hacksaw to fabricate the filter chamber. Four pieces of the perspex glass was put side by side and gum together along the edges using silicon gum to form the filter ( 30 by $30 \mathrm{~cm}$ and $100 \mathrm{~cm}$ high). The filter has a 50 litres storage tank and it is connected to the filter chamber by $25.4 \mathrm{~mm}$ diameter PVC pipe. The water outlet from the storage tank through the pipe has a control tap for regulating the flow of water from the tank into the filter chamber. The bottom of the filter chamber was covered with 30 by $30 \mathrm{~cm}$ perspex glass and it has a hole of $2.54 \mathrm{~cm}$ where drain pipe $(2.54 \mathrm{~cm}$ diameter and $8 \mathrm{~cm}$ long with control tap) is fixed. The drain pipe could be opened when there is need to remove dirty particles from the bottom of the filter chamber.

The filter chamber was filled with $10 \mathrm{~cm}$ gravel (sieved through $6 \mathrm{~mm}$ ), a silk membrane $(30$ by $30 \mathrm{~cm}$ ) was put on the gravel layer, coarse sand of gain size 0 . $35 \mathrm{~mm}$ was put after the gravel to a thickness of $20 \mathrm{~cm}$ 
and fine sand of grain size $0.20 \mathrm{~mm}$ was put on the coarse sand to a depth of $30 \mathrm{~cm}$. Granular carbon (sieved through $2 \mathrm{~mm}$ and $10 \mathrm{~cm}$ depth) enclosed in a muslin bag was put after the fine sand for the removal of some chemicals from the water. A diffuser plate using the Perspex glass $(29.8$ by $29.8 \mathrm{~cm})$ with $2 \mathrm{~mm}$ perforations spaced $2 \mathrm{~cm}$ apart was placed on the filter chamber $15 \mathrm{~cm}$ away from granular carbon. The diffuser allows flow of water from the storage water tank to be spread over the entire sand filter bed. The outlet pipe $(1.27 \mathrm{~cm}$ diameter and $15 \mathrm{~cm}$ long) for filtered water was fixed at $5 \mathrm{~cm}$ to the bottom of the filter chamber. The outlet pipe has a control tap for regulating the flow of clean water from the filter.

The exploded view of the laboratory slow sand water filter was shown in Figure 1 while the picture of the slow sand water filter was shown in Figure 2. The cost of component parts and the total cost of constructing a slow sand filter between April and May, 2017 using readily available materials in Ilorin was forty nine thousand sixty naira $(\mathrm{N} 49,060)$ as shown in Table 1 of the Bill of Engineering Measurement and Evaluation or Bill of Quantity.

Performance evaluation of the slow sand filter and water qualities analysis: The flow rate of water through the slow sand filter was determined in order to estimate the capacity or the quantity of water which the filter could produce in litre per hour or litre day. A 1 litre glass measuring cylinder was put at the outlet of the slow sand filter, the control tap of the storage tank was opened and the raw water flow from the tank into the filter chamber where the water was filtered by the granular carbon and sand particles. A stop watch was switched on immediately when water reaches the filter chamber and switched off when the cylinder was filled to 1 litre level. The flow rate (discharge) was determined using Equation (1). The average time taken by the water through the filter to fill 1 litre for three replications was $236 \mathrm{~s}$. The water qualities analyses was conducted to determine the performance evaluation of the filter were some selected physical, chemical and bacteriological properties of the water before and after filtration. Clean and sterilized plastic bottles were used to collect water samples for the analysis. The physical, chemical and bacteriological properties of the water were determined using the standard method given by AOAC (2000).

$$
\begin{gathered}
Q=\frac{V}{T} \quad(1) \\
Q=\frac{1.00}{236} \times 60 \times 60=15.25=15.3 \text { litres } / \mathrm{h}= \\
0.0153 \mathrm{~m}^{3} / \mathrm{h}
\end{gathered}
$$

Operating principles and maintenance of the slow sand filter: Quantity of raw water (like 30 litres) to be filtered is poured into the storage tank of the filter and the control tap is opened for the water to flow into the filter chamber. It takes about 5 minutes for the raw water to flow through the filter bed. Pathogens, dissolved particles, turbidity and some chemicals would be removed from the water or reduced to acceptable level. When the outlet control tap is opened, clean water would flow through the outlet and the water is collected from the outlet. Slow sand filter does not need electricity to power its operation. The slow sand filter is suitable for teaching and does not require operating cost. Maintenance of the slow sand filter is required after it has been used continuously for water filtration and observed that water could not flow through the filter due to blockage of the pores of the filter bed by accumulation of dirty particles. The maintenance is done by removing about 3 to $5 \mathrm{~cm}$ depth of the fine sand from the top layer and refill with new fine sand.

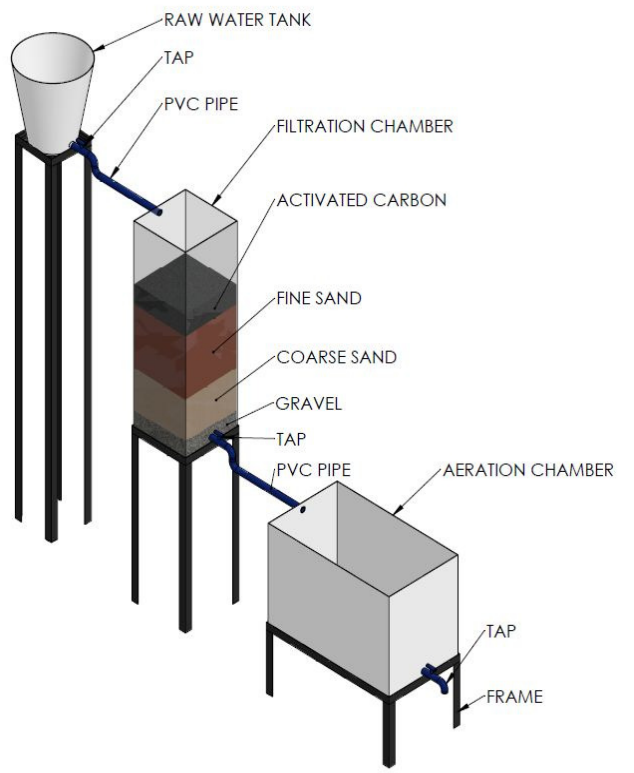

Fig 1: Exploded view of the sow sand filter.

\section{RESULTS AND DISCUSSION}

The slow sand filter has a capacity of producing 15.25 litres/h of clean water that is safe for consumption without causing .diseases to man. The results of physical, chemical and bacteriological properties of the water obtained from the filtered and non-filtered water (raw water) 4 days after the construction of the filter when the biofilm layer (schmutzdecke) has not developed was shown in Table 2. The filter reduced the turbidity by $86.42 \%$ from 6.7 NTU for non-filtered (raw water) to $0.91 \mathrm{NTU}$ after passing through the filter. 
Table 1: Bill of Engineering Measurement and Evaluation (BEME) for the slow sand filter as at April -May, 2017

\begin{tabular}{|c|c|c|c|c|c|}
\hline S/No & Item & Description & Quantity & Rate (N) & Amount (N) \\
\hline 1 & 50 litres plastic bucket & Storage tank for raw water container & 1 & 1,500 & 1,500 \\
\hline 2 & 20 litres Plastic bucket with lid & Filtered water container & 1 & 600 & 600 \\
\hline 3 & $4 \mathrm{~mm}$ thick Perspex glass $(120$ by $50 \mathrm{~cm})$ & Construction of the filter chamber & 1 & 22,000 & 22,000 \\
\hline 4 & Metal control tap & Raw water outlet & 1 & 600 & 600 \\
\hline 5 & Plastic Control tap & Filtered water outlet & 1 & 400 & 400 \\
\hline 6 & Wooden stand & Stood for storage tank & - & - & 3,500 \\
\hline 7 & PVC Pipe (1 inch) & Outlet raw water pipe & 1 & 500 & 500 \\
\hline 8 & PVC Pipe (1/2 inch) & Outlet clean water pipe & 1 & 500 & 500 \\
\hline 9 & Granular Carbon & Carbon and Membrane & - & 700 & 700 \\
\hline 10 & Silicon gum & Sealant gum for pipe connection & - & 700 & 700 \\
\hline 11 & Bulkhead fitting & Draining of dirty water & 1 & 500 & 500 \\
\hline 12 & Tigre elbow & Elbow join connection & 1 & - & 60 \\
\hline \multirow[t]{2}{*}{13} & Labour cost & $\begin{array}{l}\text { Pipe fittings and Filter chamber } \\
\text { construction }\end{array}$ & - & - & 17,500 \\
\hline & Total & - & - & - & 49,060 \\
\hline
\end{tabular}

This was in agreement with the study of Bagundol et al. (2013) that slow sand filter reduced turbidity of well water by $99 \%$ with depths of sand filter medium varied from $30-90 \mathrm{~cm}$. Effect of the slow sand filter on some selected chemical properties of water. The slow sand filter also reduced the concentrations of Calcium, Magnesium, Potassium, Sodium and Iron in the water as shown in Table 2. The concentration of iron in the raw water $(0.6 \mathrm{mg} / \mathrm{l})$ was initially above water quality limits of SON (2007) but reduced below the limits after passing through the filter. The granular carbon has ability to remove some chemicals in water because is an adsorbent agent. Effect of slow sand filter on the removal bacteriological property (pathogens) of water was not $100 \%$. The E-Coli count present in the non-filtered water (water before filtration) was 13 but the E-Coli count reduced to 4 after passing through the filter. The filter slow sand filter reduced the E-Coli present in the water by $69 \%$ but could not totally remove the E-Coli from the water as shown in Table 2 because biofilm layer had not developed within 4 days. Buzunis (1995) pointed out that biofilm layer (schmutzdecke) normally develops 2 - 3 weeks after the construction of the slow sand filter and the filter bed must be kept wet. Even when the biofilm layer has fully developed, most slow sand filters could not totally (100\%) remove pathogens from the water contaminated by pathogens. Bagundol et al. (2013) reported that the efficiency of E-Coli removal by slow sand filter depends on the depth of the sand filter media, biofilm layer and flow rate of water through the filter but the slow sand filter could not totally remove E-Coli by $100 \%$. This means that after the filtration of water in the water treatment plant, disinfectant like chlorine (chlorination) is normally added to kill the pathogens so that the water is $100 \%$ safe for consumption. From this study, undergraduate students should know that most slow sand filters could not totally $(100 \%)$ remove pathogens in the contaminated water. The filter had positive effect in the removal of turbidity, colour, electrical conductivity, removal of some chemicals and reduced the E-coli contents of microorganisms.

Table 2: Physical, chemical and bacteriological parameters of water after passing through the slow sand filter

\begin{tabular}{|c|c|c|c|}
\hline Parameter & Non-filtered water & Filtered water & SON Acts 2007 \\
\hline Taste & Mild & Tasteless & Tasteless \\
\hline Turbidity (NTU) & 6.7 & 0.91 & 5.0 \\
\hline$(\mathrm{BOD})$ & 5.6 & 0.9 & - \\
\hline Colour (TCU) & 10 & 6.8 & 15 \\
\hline $\mathrm{pH}$ & 7.2 & 6.7 & $6.5-8.5$ \\
\hline $\mathrm{EC} \mu \mathrm{S} / \mathrm{cm}$ & 83.7 & 26.8 & 1000 \\
\hline $\mathrm{Ca}^{2+}(\mathrm{mg} / \mathrm{l})$ & 28.0 & 12.6 & 200 \\
\hline $\mathrm{Mg}^{2+}(\mathrm{mg} / \mathrm{l})$ & 20.0 & 16.0 & 0.20 \\
\hline $\mathrm{K}^{+}(\mathrm{mg} / \mathrm{l})$ & 0.72 & 0.31 & - \\
\hline $\mathrm{Na}^{+}(\mathrm{mg} / \mathrm{l})$ & 1.63 & 0.82 & 200 \\
\hline Hardness $\left(\mathrm{Caco}_{3}\right)(\mathrm{mg} / \mathrm{l})$ & 48.2 & 15.8 & 150 \\
\hline $\operatorname{Iron}(\mathrm{mg} / \mathrm{l})$ & 0.65 & 0.12 & 0.30 \\
\hline Colonies $/ 100 \mathrm{ml}$ growing on nutrient agent at $37^{\circ} \mathrm{C}$ in 24 hours & 40 & 12 & - \\
\hline E-Coli cfu/100ml & 13 & 4 & 0 \\
\hline Salmoneth cfu/100ml & Nil & Nil & 0 \\
\hline
\end{tabular}

SON = Standard Organisation of Nigeria Act 2007 for drinking water quality

Conclusion: The laboratory slow sand filter was fabricated from locally available materials mainly transparent perspex glass, freely running sand, plastic bucket and PVC pipe. The filter reduced the turbidity 
by $86.42 \%$ and reduced the some chemicals in the water to water quality limits. The slow sand filter in this study reduced E-Coli count by $69 \%$. The filter and most other slow sand filters could not totally remove faecal coliform and pathogens from the water in order to make high contaminated water by pathogens safe for consumption. It is recommended that the slow sand filter should be used for purification of water in the laboratory for teaching and disinfectant must be added to the water after filtration to kill all the pathogens because most slow sand filters could not totally remove some of the deadly pathogens in the contaminated water.

\section{REFERENCES}

AOAC (2000). Official Methods of Analysis of the Association of Official Analytical Chemists 15th Edition, Arlington, Virginia, USA.

Bagundol, TB; Awa, AL and Enguito, MRC (2013). Efficiency of Slow Sand Filter in Purifying Well Water. Journal of Multidisciplinary Studies, 2 (1): 86-102.

Basak, NN (2003). Environmental Engineering, Tata McGraw-Hill Publishing Company Ltd, New Delhi, 90 - 98.

Buzunis, B (1995). Intermittently Operated Slow Sand Filtration, Unpublished M.Eng Thesis. The University of Calgary, Calgary, Canada.

Chatterjee, A K (2010). Water supply, waste disposal and Environmental Engineering. Khanns Publishers, New Delhi, 242 - 250.

EL-harbawi, M; Sabidi, AA; Kamarudin, E; Abdhamid, A; Harun, S; Nazlan, A and Xiyi, C (2010). Design of a portable dual purposes water filter system, Journal of Engineering Sci. Technol. 5 (2): 165 - 175

Hammer, MJ and Hammer, MJ (2012). Water and wastewater technology, $7^{\text {th }}$ Edition, PHI Learning Private Ltd, New Delhi, 40 - 50.
Hendricks, D (Ed.) (1991). Manual of Design for Slow Sand Filtration, Barrett, JM; Bryck, J; Collins, MR; Janois, BA and Logsdon, GS (authors), published by AWWA Research Foundation and American Water Works Association, Denver, Colorado.

Lahlou, M (2000). Slow Sand Filtration. Tech Brief, N. E. S. Center, Ed. Morgantown, W. V. Shoemaker, $\mathrm{T}$ (2014). Determining the viability and effectiveness of a roughing biofilter for use in drinking water treatment plants. M.Sc. Thesis submitted to Faculty of the Graduate School, University of Missouri-Columbia.

Simpson, DR (2008). Biofilm processes in biologically active carbon water purification. Water Research, 42 (12): 2839 - 2848.)

SON (2007). Nigerian Standard for Drinking Water quality, 1-30.

Visscher, JT; Paramasivam, R; Raman, A and Heijnen, HA (1987). Slow sand filtration for community water supply - planning, design, construction, operation and maintenance, Technical Paper Series 24, June 1987, International Reference Centre

(IRC) for Community Water Supply and Sanitation, Netherlands.

WHO (1996). Guidelines for Drinking-Water Quality - Health Criteria and other Supporting Information, Second Edition, World Health Organisation, Geneva.

Wirojanagud, W; Hovichitr, P; Chomvarian, C; Bunyakarn, $\mathrm{P}$ and Auyyanonda, $\mathrm{S}$ (1989).Evaluation of rain water quality: heavy metals and pathogens. Final report submitted to IDRC, Canada: 104. 